\title{
THE POLYSTYRENE VACUUM WHEELCHAIR CUSHION
}

\author{
By H. W. Francis Jones and Miss Anne Evans \\ Midland Spinal Injuries Unit, Robert fones and Agnes Hunt Orthopaedic Hospital, \\ Oswestry, Salop, England
}

Abstract. A polystyrene bead vacuum wheelchair cushion has been tried with several patients with abnormal postural reflex activity. Excess spasticity can be reduced by this means and sitting comfort enhanced.

Key words: Wheelchair cushion; Posture; Spasticity; Decubitus.

THE well rehabilitated and trained paraplegic does not present much of a problem when it comes to wheelchair cushioning. However, there are other cases, an unfortunate minority, where there is a most challenging problem. There is a whole spectrum of difficulty at one end of which is the patient of abnormal shapespactic as well-and often with asymmetry of muscle tone.

We are all familiar with these cases, who, when they have sensory loss too, come to need repeated and prolonged spells of costly hospital treatment for pressure sores. This investigation is concerned only with these cases of special difficulty.

The patient with spastic paralysis is not just a weight to be supported; because of his increased and ungoverned postural reflexes his cushioning problems often call for more than the mere application of Archimedean principles.

Among physiotherapists it is standard practice to place the limbs in a position opposed to the predominant spastic pattern before treatment or before functional activities. The relaxation so provided is often only fleeting but abnormal reflex activity can be inhibited by maintaining limbs in correct postures.

For the patients of abnormal and asymmetric shape with spasticity we have been considering the advantages of a firmer support which can be moulded to support the 'wind-swept' pelvis, the trunk of a scoliotic, lordotic hollows and, if need be, the head and neck in a cerebral plasy patient.

The vacuum polystyrene bead cushion, the principle of which is well known, 'freezes' in the moulded position when the air is pumped out of it. This wheelchair version of the device is made in three separate compartments, the seat, the back and head and neck sections; the latter can be folded down if not in use. This particular cushion is rather bulky and it is only a prototype.

Our first trial of the vacuum cushion was with a I9-year-old youth with spastic tetraparesis due to hypoxic brain damage sustained in early childhood. His devoted parents had become utterly exhausted by the need to reposition him in his chair every hour or so throughout the day. They were much distressed at having to watch his discomfort, repeatedly mount into pain as he gradually lost his stability in the sitting position.

The sitting position was severely affected by the asymmetrical distribution of muscle tone; this was caused by the influence of abnormal postural reflex activity. This disorder of reflexes had led to the development of spinal and hip deformities. Extensor tone in the lower limbs was accentuated, predominantly on the left side and this caused him to slide forward in the chair. Hypertonus was further increased as the sitting position became more insecure. 
The moulded support provided by the cushion successfully overcomes the effect of the abnormal postural reflex activity.

This patient was soon able to maintain a comfortable and stable sitting position. Hypertonus was much diminished and flexor spasms disappeared. The left hip which used to remain obdurately extended became relaxed and allowed a more comfortable and secure sitting position.

Sweating was observed to be less and there were no skin problems.

At present this youth is back at home and he sits on the vacuum cushion all day. From time to time-every two hours or so-his position is checked and the vacuum may have to be 'topped up' by a little more pumping. His parents are very pleased with the results; they find, too, that the cushion allows the boy to travel much more comfortably by car.

Several cerebral palsied children with severe sitting posture difficulties were next tested on the vacuum cushion. Correct, secure and comfortable sitting position could be maintained in most cases and excess spasticity was reduced.

In the few high-level tetraplegic patients we have tried out on the cushion there has been a good result with enhanced trunk stability; excess spasticity and the forward slide tendency were reduced.

In its present form the cushion is less suited to the paraplegic patient but the makers contemplate producing it in a modular design so that the seat section can be detached and used alone. This may have a wider use in spinal injury units. The active and independent paraplegic who is able to do his own 'transfers' is not suited for this cushion and, indeed, he has no need for it; this is a cushion for 'special cases' only.

The several spastic and asymmetric paraplegic patients we have tried on the cushion in its present form have been made comfortable. Excess spasticity of hip adductors, in particular, has been corrected and forward slide prevented too.

In cord lesions, with problems of severe extensor spasticity, the cushion can secure the trunk and limbs in a position where components of the predominant extensor pattern are broken up. For example the boy shown on this slide has a D6 cord lesion with marked crossed extensor spasticity of both legs, causing him to slide forward in his chair, thus preventing not only a comfortable and stable sitting posture but also preventing him from pushing his chair easily.

Skin problems-sores or induration-have not been seen so far although there must be need for extra vigilance.

Our findings to date are tentative but show enough promise to encourage us to try the later versions of the cushion in other cases.

The most suitable cases seem to be the asymmetric paraplegic with abnormal postural reflex activity and the high cervical case with trunk instability. Forward slide seems to be overcome in these patients.

Of course this investigation is not by any means original and $I$ think it is likely that other members of the Medical Society have made similar trials. We have, at this stage, more questions than answers.

\section{SUMMARY}

A wheelchair cushion capable of being contoured to support the thighs, buttocks, back and, if necessary, the head and neck has been tried out with patients having excess spasticity and postural problems.

The cushion contains polystyrene beads and it 'freezes' into a moulded shape when the air is pumped out. 
There may be a place for this type of wheelchair cushion in the care of spastic paraplegia and tetraplegia, cerebral palsy and in patients of asymmetric shape and with abnormal posture reflexes.

\section{RÉSUMÉ}

Des expériences ont été faites avec des patients argent un excés de (spasticité) et des problemes de postures sur des chaises roulantes argant des coussins à rembourrage special pouvrant embrasser les formes tels que partié arrierè de la cuisse, fessier, des et si necéssaire tête et cou.

Le coussin contient des boules de polestyrène et il enveloppe les formes quand l'air est aspiré.

Le type de coussins pour chaise roulante pourrait être utilisé dans les cas de soins au paraplégiques, tetraplégiques et les malaeds atteints de paralysic cérébrale ainsi que pour certains patients présentants des diformités et des réflexes de postures, anormaux.

\section{ZUSAMMENFASSUNG}

Ein Rollstuhl Kissen, das durch seine Kontur die Oberschenkel, die Hinterseite und, wenn nötig, Kopf und Nacken unterstützt, wurde in Patienten mit starker Spastizität angewandt.

Das Kissen enthält Polysterene Kugeln und "friert" in in ein Modell when die Luft ausgepumpt wird. 